\title{
Evaluation of Lifelong Work Satisfaction among Former Postal Service Workers'
}

I Miira Niska ${ }^{2 \ddagger}$

Postdoctoral researcher, Faculty of Social Sciences (Unit of Social Research), Tampere University, Tampere, Finland

I Prakash, K. C. $\ddagger$

Postdoctoral researcher, Faculty of Social Sciences (Unit of Health Sciences), Gerontology Research Center, Tampere University, Finland

\section{- Anna Siukola}

Postdoctoral researcher, Faculty of Social Sciences (Unit of Health Sciences), Gerontology Research Center, Tampere University, Finland

I Hanna Kosonen

Research assistant, Faculty of Social Sciences (Unit of Health Sciences), Tampere University, Finland

I Jari Luomanen

Postdoctoral researcher, Faculty of Social Sciences (Unit of Social Research), Tampere University, Finland

I Kirsi Lumme-Sandt

University lecturer, Faculty of Social Sciences (Unit of Health Sciences), Gerontology Research Center, Tampere University, Finland

\section{Subas Neupane}

Postdoctoral researcher, Faculty of Social Sciences (Unit of Health Sciences), Gerontology Research Center, Tampere University, Finland

I Pirjo Nikander

Research director, The Doctoral School, Tampere University, Finland

I Clas-Håkan Nygård

Professor, Faculty of Social Sciences (Unit of Health Sciences), Gerontology Research Center, Tampere University, Finland

\footnotetext{
${ }^{1}$ You can find this text and its DOI at https://tidsskrift.dk/njwls/index.

${ }^{2}$ Corresponding author: Miira Niska, Faculty of Social Sciences (Unit of Social Research), 33014 Tampere University, Finland. E-mail: miira.niska@tuni.fi. ‡ Contributed equally.
} 


\begin{abstract}
While policymakers emphasize the need to delay retirement age, numerous traditional industries, among them postal services, emphasize the need for employee downsizings. These can be contradictory needs. Downsizings can reduce work life satisfaction (WLS) among workers, and reduced WLS can decrease willingness to delay retirement age. In this cross-sectional study, we explore WLS trajectories of former postal service workers by analyzing quantitative survey data $(N=201)$ and qualitative interview data $(N=40)$. In the data, workers aged 50-67 years evaluate their lifelong work satisfaction. The results of the quantitative and the qualitative study complement and mirror each other. Same trajectories of WLS were identified in both data. One-third of the survey respondents reported decreasing WLS, which according to the qualitative data relates to employee downsizings. The article highlights the importance of acknowledging contextual elements of work satisfaction measurement and the benefits of combining methodological traditions to understand the longer-term dynamics involved.
\end{abstract}

\title{
KEYWORDS
}

Employee downsizing / extended working life / lifeline trajectories / mixing methods / older workers / work life satisfaction

\section{Introduction}

- ecent demographic shifts have triggered a strong political need to delay retirement age and extend working lives. Over the past ten years, the population of Nordic countries has aged even faster than in many other European countries (Grunfelder et al. 2018a). As the old age dependency ratio increases, pushing the average retirement age further is an appealing proposition when compared against raising taxes or cutting pensions (Eläketurvakeskus 2013; European Commission 2010; Hess 2017; OECD 2017; Wise 2010). At the same time, the labor market is seeing major shifts. In the future, automation and digitalization can take over as much as 40 per cent of working hours in Nordic countries (Grunfelder et al. 2018b). Together with globalization, automation and digitalization have forced numerous traditional industries to invoke downsizing strategies that include, for example, early retirement incentives and layoffs (Grunfelder et al. 2018b; Macky 2004; McMullin \& Marshall 2001).

Previous studies have reported the association of downsizing practices with negative psychological responses like reduced work satisfaction (Datta et al. 2010). According to the classic definition, work satisfaction is a positive emotional state that results from one's appraisal of one's work (Locke 1976: 1300; also Spector 1997). In this article, our focus is on work life satisfaction (WLS). With this concept, we refer to work satisfaction throughout life. Work satisfaction is vital for individuals' wellbeing and happiness (Bojanowska \& Zalewska 2016), but it is also vital for companies and successful extension of working lives: low work satisfaction associates with retirement intentions and absenteeism from work (Harkonmäki et al. 2009; Kadefors et al. 2016; Sagie 1998). If downsizing practices lower work satisfaction, they may hinder the extension of work careers in two ways: older victims face difficulties in finding new employment (Armstrong-Stassen \& Cattaneo 2010; Furunes \& Mykletun 2010; Solem 2015), and older survivors start thinking about early retirement (Badran \& Kafafy 2008; van den Berg et al. 2010).

Work satisfaction has been the topic of active scientific inquiry (Berglund et al. 2017; Bussing et al. 1999; Kadefors et al. 2016; Pagán 2013). Previous quantitative 
studies demonstrate that work-related resources (Stynen et al. 2017), job support (Pagán 2013) and job control (Allan et al. 2018; Chao et al. 2015; Lindfors et al. 2007; Meyers et al. 2019; Waddimba et al. 2016) are positive predictors of work satisfaction. Similarly, work engagement (Meyers et al. 2019; Shimazu \& Schaufeli 2009) and work status (Navarro \& Salverda 2019; Tay \& Harter 2013; Virtanen et al. 2003) play a significant role in work satisfaction of workers in various sectors. In addition, poor perceived health (Lunau et al. 2014; Mäkikangas \& Kinnunen 2003), increased number of sick leave days (Kuoppala et al. 2011), organizational injustice (Lindfors et al. 2007; Meier et al. 2015; Pagán 2013) and irregular working hours (Lunau et al. 2014) have the potential to degrade work satisfaction. Likewise, poor quality of work environment (Siegrist et al. 2007), employee age, their tenure period at work and working level, that is, the professional level or place in the workplace/company hierarchy (Ramoo et al. 2013) could reduce wellbeing at work and ultimately result in premature exit from the labor market.

Quantitative studies on work satisfaction have been criticized for disregarding the particular historical and social context and nature of individuals' work satisfaction evaluations (Zembylas \& Papanastasiou 2006). Whereas Bojanowska and Zalewska (2016) call for studies on lay conceptions of happiness, Zembylas and Papanastasiou (2006) call for studies on lay conceptions of work satisfaction. Researchers have also conducted a substantial amount of qualitative studies on work satisfaction (Atefi et al. 2014; Bussing et al. 1999; de Wesley \& Clemson 1992; McNeese-Smith 1999; Moore et al. 2006). These individual interview and focus group based studies have mapped the lay conceptions of work satisfaction, for example, of teachers in Cyprus, nurses in Iran and occupational therapists in Australia. In line with quantitative studies, qualitative studies have demonstrated that social relations, working conditions and resources have an effect on work satisfaction (Atefi et al. 2014; McNeese-Smith 1999; Moore et al. 2006; Zembylas \& Papanastasiou 2006). Furthermore, qualitative studies have disclosed context-specific conceptions of work satisfaction. Iranian nurses, for example, reported that Iranian, doctor-centered culture decreases their work satisfaction (Atefi et al. 2014). Cypriot teachers reported that the centralization of the Cypriot educational system decreases their work satisfaction (Zembylas \& Papanastasiou 2006). Considering these context-specific conceptions of work satisfaction, it might be insufficient to measure work satisfaction solely in quantitative terms, and thus overlook the possibilities of qualitative research (Bussing et al. 1999).

In this article, we study evaluations of lifelong work satisfaction of Finnish postal service workers. The postal service sector all over the world faces massive transformations due to progressive digitalization and diminishing amount of traditional paper mail (Dieke et al. 2013). In Finland, the state-owned company Posti Group has undergone significant structural and operational changes, such as company acquisitions, mergers, selling parts of the company, and renewals in services and operations. Posti Group, formerly Itella and Suomen Posti, used to have a reputation as a stable and reliable employer (Pietiäinen 1998). Posti Group has also been one of the largest corporate employers in Finland. However, over the last decades, Posti Group has been laying off its personnel. Finland has a law about cooperation in companies (334/2007), which promotes interactional cooperation procedures between employers and employees. When companies with more than 20 employees make changes that affect these employees, such as downsizings, the employer is legally obligated to negotiate with the employees about the reasons, impacts and alternatives for those changes. In case of dismissals and 
layoffs, the company is also responsible for making a motion for employees' re-employment promotion, potentially in collaboration with public employment agencies. Since 2011, Posti Group has undertaken several cooperation negotiations yearly (Posti annual reports 2011-2016). After the cooperation negotiations of 2014, around 780 people were laid off (Posti annual report 2014, p. 150). Previous research has demonstrated that a fair downsizing process can actually mitigate negative employee responses such as reducing work satisfaction (Datta et al. 2010; Macky 2004). Has Posti Group been able to conduct downsizings in a way that prevents reductions in its employees' work satisfaction? The purpose of this research is to increase knowledge about the trajectories of lifelong work satisfaction in the context of company downsizing. The aim is to facilitate decision-making and hopefully inspire further research in the field of work satisfaction studies.

Work life satisfaction is a significant concern in terms of the overall health and development of the individual worker (Lunau et al. 2014), and as such carries across important public health outcomes and effects. Due to massive layoffs, former workers of the Posti Group represent a unique group for the study of WLS transitions in the context of company downsizing. In order to find out whether constant cooperation negotiations and employee downsizings have reduced employees' WLS, we study WLS trajectories from both quantitative and qualitative perspectives. Most quantitative studies have targeted the WLS at a particular point. However, to map the possible changes, our quantitative study investigates retrospectively the developmental pathways of WLS. The quantitative study also describes the cross-distribution of different basic and work-related characteristics of the study population and their membership in different developmental pathways of WLS. To deepen our understanding of the social context of WLS trajectories (see Spector 1997), we also analyze narratives, or stories, of temporal changes in interviewees' subjective work satisfaction. We believe that this cross-fertilization - or mixing of two different methodologies - provides a rich description of postal workers' WLS transitions and their causes.

\section{Materials and Methods}

To examine postal workers' work satisfaction trajectories throughout life, we analyze quantitative and qualitative data generated in a research project Towards a two-speed Finland? (2015-2019). In the data, former postal service workers over the age of 50 evaluate their lifelong work satisfaction.

\section{The quantitative data}

Initially, a survey questionnaire was sent to 4386 Finnish postal service workers and $44 \%$ of them responded. The selection of the laid-off respondents for the cross-sectional quantitative study is based on a survey questionnaire, sent in 2018, to 1935 study subjects who were actively working for Posti Group until 2016. A total of 1466 responded, yielding a response rate of $76 \%$. Around $86 \%$ of the respondents were still working in Posti Group and the rest $(n=212)$ were no longer working in Posti Group (laid-off). In the analysis, we studied the laid-off respondents who replied to the questionnaire in 
2016 regarding their WLS level at 15-29 years, 50-59 years and in at least one of the intervening lifetime points (either 30-39 years or 40-49 years or both). The inclusion criteria resulted in the selection of 201 respondents.

\section{Satisfaction in working life (WLS)}

The satisfaction level of respondents during the ages of ' $15-29$ ', '30-39', '40-49', '50-59' and '60-69' was asked using questionnaire. The responses were collected on a scale of ' 0 ' (very dissatisfied) - ' 10 ' (very satisfied). Since a large proportion of the respondents were around 50-59 years of age, the question regarding their satisfaction during '60-69' years of age was not included, which was a proceeding question and potential to information bias. The single item to measure WLS has been previously validated (Dolbier et al. 2005).

\section{Work ability}

The first item of work ability index questionnaire was used to assess the current work ability (Jääskeläinen et al. 2016). The respondents were asked to rate their current work ability compared to life's best using a scale of $0-10$ where ' 0 ' indicated the worst and ' 10 ' indicated the best. The responses were categorized into Poor (0-5), Reasonable $(6-7)$, Good (8-9) and Excellent (10). The categories Good and Excellent were merged to be used as Good/Excellent work ability in the present analysis. The Good and Excellent categories of work ability were merged because there were very minimal to no differences in trajectory groups with respect to these two categories, and after merging, the single category was more representative.

\section{Job support and Job control}

Job support was assessed with questions related to feedback from supervisors, support from supervisors and support from workmates, which were answered on a scale of ' 0 to 10', where zero indicates low support and ten indicates a high level of support. The summary score of five job support items (Cronbach's $\alpha=0.78$ ) ranging from 8 to 50 was dichotomized into 'high' and 'low' using the median value (36.0) (von Bonsdorff et al. 2012). Job control was assessed with questions related to the respondent's possibility to learn new knowledge and skills $(0-10)$, possibility to influence work and working conditions (1-4), an experience of doing important and significant work (1-6) and enough education at work (0-10) (von Bonsdorff et al. 2012). The summary score of four job control items (Cronbach's $\alpha=0.73$ ) ranging from 0 to 27 was dichotomized into 'high' and 'low' using the median value (17.0).

\section{Covariates}

The age of the respondents ranged from 51 to 67 years. The gender of the respondents was elucidated as women and men. Two occupational classes, white collar (includes 
professional, managerial and administrative work) and blue collar (includes manual labor and customer interaction), were used. The tenure period in Posti Group was assessed in a count of years and working time was assessed as working hours per week. The number of sickness absence days per year was assessed in a count of days and is dichotomized into ' $0-14$ ' and ' $15-365$ ' days to be used in this study. The level of education is elucidated into three categories (basic schooling, college level training and academic degree). The self-reported responses on the presence of physician-diagnosed disease were assessed using yes/no questions. Likewise, equality at work was assessed using a yes/no question. Perceived health was assessed using a single item 'How do you rate your current health compared to your life's best?', and responses were collected on a scale of ' $0-10$ '. Those responses were categorized into good (9-10), moderate (7-8) and poor/fair (0-6) to use in this study. The selection of the variables was partly based on previous literature (Dolbier et al. 2005; Ramoo et al. 2013; Siegrist et al. 2007).

\section{The qualitative data}

The qualitative data we use originate from a more extensive qualitative research project based on longitudinal qualitative research (e.g., Neale 2019). For the benefits of this article, we focus on data from the first interview round where interviewees $(N=40)$ evaluated their lifelong work satisfaction (for overall data generated in the project, see table A1 in Appendix). In these first round interviews, research participants were asked to draw their WLS lifelines on a coordinate plane where the $\mathrm{x}$-axis mapped age $(20$, $30,40,50,60,70$ ), and the $y$-axis mapped WLS (example of a lifeline, see figure A1 in Appendix). While drawing the lifelines, interviewees narrated how their work satisfaction had changed over the years. At the time of the first interviews, 20 participants were 50-59 years of age and 20 were 60-65 years of age. Most interviewees $(n=17)$ were female, blue-collar workers. The other interviewees were male blue-collar workers $(n=8)$, female white-collar workers $(n=8)$ and male white-collar workers $(n=7)$. The interviews were recorded and transcribed verbatim in Finnish. For the benefits of transparency and validity, we present the original data excerpt transcriptions in Finnish alongside their translations into English. This is a commonly used means of securing the validity and guaranteeing the publicly verifiable, transparent nature of the qualitative analysis (Nikander 2008).

\section{Data analysis}

Mixture modelling was used to detect the developmental pathways of WLS. Latent class analysis (LCA) was used with continuous latent class indicators and user-specified starting values based on the continuous responses of the self-reported question of WLS at four lifetime points in a cross-sectional data. The responses on working life satisfaction at ages ' $15-29$ ', '30-39', '40-49' and '50-59' were used in the original form to detect the most probable developmental pathways termed as trajectories of satisfaction in working life in this study. LCA is a method that identifies within the data, the multiple latent classes that tend to have a similar development over time (Muthén 2003). We fitted the mixture model with two to four classes and selected the best-fitted model. The

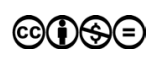


selection of the best-fitted model was based on Bayesian Information Criterion (BIC), Akaike Information Criterion (AIC), substantive interpretability of classes, parsimony and entropy (Muthén 2003; Nylund et al. 2007). The fit indices are presented in detail in Table 1. The four-class model had the lowest BIC value and the lowest AIC value. Therefore, we favored the four-class model that had the distinct development patterns of all the four classes, higher entropy, and higher average posterior probability. The four-class model gave us the latent classes that represent low, decreasing, moderate and high WLS, respectively. The differences in basic and work-related characteristics of the study subjects were tabulated according to trajectories of WLS with a significance level of $\mathrm{p}<0.05$. The differences in continuous variables were tested using analysis of variance and differences in categorical variables using the $\chi 2$ test. The mixture modeling was done in Mplus version 7.11 (Muthen and Muthen, 3463 Stoner Ave., Los Angeles, CA) and other analyses were done in STATA 14.0 (StataCorp LP, College Station, Texas 77845, USA).

Table I Fit-indices for trajectories of satisfaction in working life among post office workers

\begin{tabular}{ccccc}
\hline Classes & BIC & AIC & Entropy & Posterior probability \\
\hline 2 & 27466.58 & 27371.44 & 0.73 & $0.92 / 0.93$ \\
3 & 26528.19 & 26382.68 & 0.73 & $0.91 / 0.89 / 0.86$ \\
4 & 25934.67 & 25738.79 & 0.75 & $0.87 / 0.88 / 0.92 / 0.84$ \\
\hline
\end{tabular}

BIC, Bayesian Information Criteria; AIC, Akaike Information Criteria

The qualitative interview data were analyzed as narratives of subjective WLS. In line with Flanagan (1954), we focused on critical incidents, which structure the narratives by either increasing or reducing the narrator's subjective WLS (see also Butterfield et al. 2005). Critical incidents are common resources for narratives. Because they are especially meaningful for narrators, they are also well remembered. In critical incidents technique, key incidents are identified in a data-driven, bottom-up fashion from the transcribed interview materials (Butterfield et al. 2005, p. 481-483). In this study, the analysis proceeded as follows. The transcriptions and work satisfaction lifeline drawings were processed together. The critical incidents described in the interviews and marked on the drawings were categorized into ones that took place when the narrator was 20-29, 30-39, 40-49 and 50-59 years old. Since the evaluation of work satisfaction at the age of 60-69 was omitted from the quantitative study, this was also mirrored in the qualitative study. Next, all incidents were classified into (a) ones that increased WLS and (b) ones that reduced WLS.

\section{Results}

Four distinct pathways of WLS were identified through quantitative analysis: high (27\%), moderate $(32 \%)$, decreasing $(30 \%)$ and low $(11 \%)$. The developmental pathways of WLS for laid-offs are shown in Figure 1. WLS was mostly increasing or constant from 15-29 years to 30-39 years for the low, moderate and high trajectory groups. However, for the decreasing trajectory group, WLS had already started decreasing at 15-29 years and sharply decreased after 30-39 years of age. The membership of basic and work-related characteristics in trajectories of satisfaction in working life are described in Table 2. Of the total 201 selected respondents, $43 \%$ were women and $57 \%$ were men. The mean 
age of the respondents was significantly different among trajectory groups. Those in the high and moderate trajectory group were the oldest $(60.2 \pm 3.7$ years, for high trajectory group) and the decreasing group was the youngest (56.9 \pm 3.4 years). The proportion of white-collar workers was $21 \%$ and the occupational class of the respondents was not significantly different between WLS trajectory groups. There was a significant difference in perceived health of the respondents among the WLS groups. Around two-fifths of the respondents had reported their perceived health to be poor and almost half of them represented decreasing WLS. Around $50 \%$ of the respondents had basic schooling and there was no significant difference in educational status among the trajectory groups. Around $42 \%$ of the respondents had 15-365 days of sickness absence and out of that $47 \%$ represented decreasing WLS.

Figure I Trajectories of working life satisfaction among post service laid-offs in 2018.

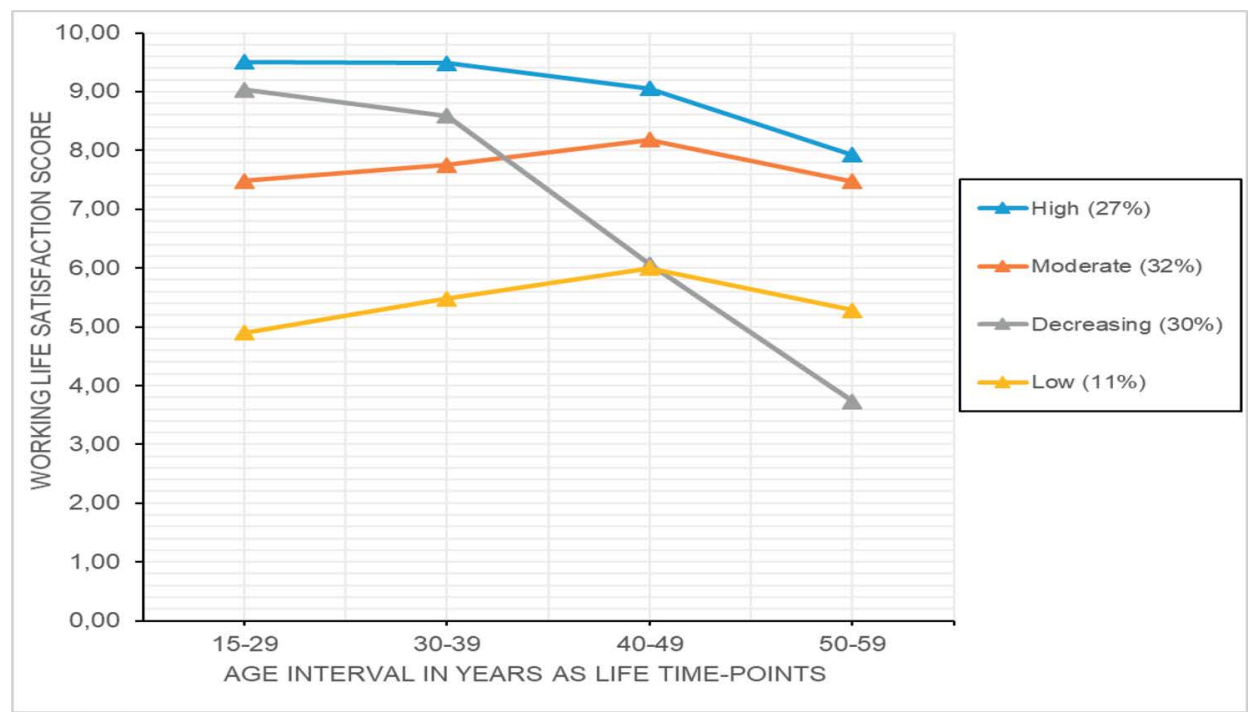

Table 2 Distribution of basic and work-related characteristics of the study population in four different trajectories of satisfaction in working life (WLS) among Posti Group laid-offs

\begin{tabular}{|c|c|c|c|c|c|c|}
\hline \multirow{2}{*}{$\begin{array}{l}\text { Characteristics of } \\
\text { the study population }\end{array}$} & \multirow{2}{*}{$\begin{array}{l}\mathbf{N} \\
(201)\end{array}$} & \multicolumn{5}{|c|}{$\begin{array}{l}\text { Membership of trajectories of satisfaction } \\
\text { in working life }\end{array}$} \\
\hline & & \begin{tabular}{|c|} 
High \\
$(\mathbf{n}=\mathbf{5 4}), \%$
\end{tabular} & $\begin{array}{c}\text { Moderate } \\
(n=65), \%\end{array}$ & $\begin{array}{c}\text { Decreasing } \\
(n=61), \%\end{array}$ & $\begin{array}{c}\text { Low } \\
(\mathbf{n}=21), \%\end{array}$ & $p$-value \\
\hline $\begin{array}{l}\text { Age }^{\mathrm{a}} \\
\text { Gender }\end{array}$ & $58.9 \pm 3.9$ & $60.2 \pm 3.7$ & $60.2 \pm 3.4$ & $56.9 \pm 3.7$ & $58.1 \pm 3.3$ & $<\left.0.00\right|^{c}$ \\
\hline Women & 85 & 31 & 34 & 28 & 7 & 0.434 \\
\hline Men & 116 & 24 & 31 & 32 & 13 & \\
\hline \multicolumn{7}{|l|}{ Occupational class } \\
\hline White-collar & 40 & 23 & 45 & 23 & 10 & 0.291 \\
\hline Blue-collar & 153 & 28 & 29 & 33 & 11 & \\
\hline
\end{tabular}




\begin{tabular}{|c|c|c|c|c|c|c|}
\hline \multirow{2}{*}{$\begin{array}{l}\text { Characteristics of } \\
\text { the study population }\end{array}$} & \multirow{2}{*}{$\begin{array}{l}\mathbf{N} \\
(201)\end{array}$} & \multicolumn{5}{|c|}{$\begin{array}{l}\text { Membership of trajectories of satisfaction } \\
\text { in working life }\end{array}$} \\
\hline & & $\begin{array}{c}\begin{array}{c}\text { High } \\
(n=54), \%\end{array} \\
\end{array}$ & $\begin{array}{c}\text { Moderate } \\
(n=65), \%\end{array}$ & $\begin{array}{c}\text { Decreasing } \\
(n=61), \%\end{array}$ & $\begin{array}{c}\text { Low } \\
(n=2 I), \%\end{array}$ & p-value \\
\hline \multicolumn{7}{|l|}{ Chronic diseases } \\
\hline Yes & 39 & 28 & 26 & 31 & 15 & 0.607 \\
\hline \multicolumn{7}{|l|}{ Perceived Health } \\
\hline Good & 56 & 23 & 45 & 20 & 10 & 0.005 \\
\hline Moderate & 67 & 34 & 35 & 21 & 10 & \\
\hline Poor & 77 & 22 & 22 & 47 & 9 & \\
\hline \multicolumn{7}{|l|}{ Educational status } \\
\hline Academic degree & 53 & 34 & 36 & 19 & II & 0.416 \\
\hline College Training & 57 & 23 & 33 & 37 & 7 & \\
\hline Basic Schooling & 91 & 25 & 30 & 33 & 12 & \\
\hline \multicolumn{7}{|l|}{ Sickness absence } \\
\hline 0-14 days & 106 & 29 & 43 & 19 & 9 & $<0.001$ \\
\hline 15-365 days & 77 & 22 & 19 & 47 & 12 & \\
\hline Work hours/week ${ }^{\mathrm{a}}$ & $33.9 \pm 9.0$ & $34.3 \pm 7.9$ & $35.3 \pm 9.5$ & $33.5 \pm 9.1$ & $29.9 \pm 9.1$ & $0.132^{c}$ \\
\hline Tenure in years ${ }^{\mathrm{a}}$ & $28.2 \pm 12.1$ & $30.1 \pm 11.3$ & $27.9 \pm 12.3$ & $27.8 \pm 12.2$ & $25.5 \pm 12.9$ & $0.498^{c}$ \\
\hline \multicolumn{7}{|l|}{ Equality at job } \\
\hline No & 72 & 22 & 24 & 43 & 11 & 0.016 \\
\hline Yes & 125 & 29 & 39 & 22 & 10 & \\
\hline \multicolumn{7}{|l|}{ Work ability } \\
\hline Poor & 79 & 25 & 24 & 43 & 8 & $<0.001$ \\
\hline Moderate & 62 & 26 & 34 & 29 & 11 & \\
\hline Good/Excellent & 59 & 31 & 43 & 13 & 13 & \\
\hline \multicolumn{7}{|l|}{ Job support } \\
\hline Low & 122 & 25 & 27 & 41 & 9 & $<0.001$ \\
\hline High & 79 & 29 & 44 & 14 & 13 & \\
\hline \multicolumn{7}{|l|}{ Job control } \\
\hline Low & 126 & 21 & 25 & 44 & 10 & $<0.001$ \\
\hline High & 75 & 36 & 45 & 8 & | | & \\
\hline
\end{tabular}

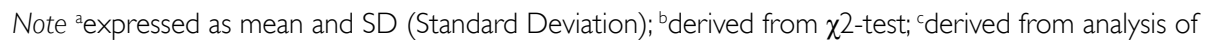
variance

The average amount of working hours per week among our study subjects was 33.9 hours (SD 9.0) and the average number of tenure years in Posti Group was 28.2 years (SD 12.1), however, none of these were significantly different between WLS trajectory groups. The proportion of good/excellent, moderate and poor work ability was $30 \%$, 
$31 \%$ and $39 \%$ respectively, and $43 \%$ of the respondents in poor work ability represented decreasing WLS compared to $13 \%$ of the respondents with good/excellent work ability. Likewise, $61 \%$ of the respondents had low job support and $41 \%$ of those in low job support represented decreasing WLS. The proportion of respondents with low job control was $63 \%$ and $44 \%$ of these respondents represented decreasing WLS. Almost two-thirds of the respondents reported that they were treated equally at work, and $43 \%$ of those who reported they were not treated equally represented decreasing WLS. The chance of having a sharply decreasing developmental pathway of WLS was higher among men, those with poor perceived health, higher number of sickness absence days, poor work ability, low job control and low job support. In addition, those who reported a lack of equality at work had a higher chance of having decreased WLS compared to those who felt that they had equality at work.

The quantitative analysis demonstrates that nearly one-third of the respondents evaluated that their WLS had reduced over time. Although work-related factors like experiences of unequal treatment, low job support and low job control were connected with decreasing WLS, the quantitative analysis does not disclose whether respondents, associate these experiences specifically with employee cooperation negotiations and employee downsizings. The qualitative part of our study, nevertheless, helped to bridge this gap, and deepened our understanding of WLS trajectories by providing verbalized information on lay conceptions of WLS transitions.

The qualitative analysis of the interview data indicates three basic storylines: continuous high or moderately high WLS, continuous low WLS and decreasing WLS. Five interviewees $(12.5 \%)$ argued that their WLS has been stable and their lifelines consisted of horizontal lines. Four out of these five interviewees narrated continuous high or moderately high work satisfaction. These interviewees described a career at Posti Group as pleasant, progressive and secure. For example, interviewee number nine argued that he has always enjoyed his work and that his job has also been a secure one.

\section{Excerpt 1}

1 I think I may have been thirty

$231,32,33$, when I started

3 ((in the postal service))

4 I can't mark down anything else here

5 cause, like I said, I've just always

6 liked my job. Like this makes crude

7 reading [laughs]. - - and see also the fact

8 that I've never been unemployed.

(I9, blue-collar worker, male, 61)
Olisinkohan mä ollu kolmenkymmenen, yks kaks kolme, kun mä oon menny ((Postiin)).

En mä nyt tännekään voi laittaa muuta kun, niin kun sanoin että kun mä oon vaan tykänny työstäni. Että täähän karua luettavaa [nauraa].- - niin kato sitten sekin vielä, että mä en oo ollu työttömänä koskaan.

On line 4, interviewee number nine refers to his horizontal work satisfaction lifeline ('I can't mark down anything else'). In line with the results of previous qualitative studies (Atefi et al. 2014; McNeese-Smith 1999; Moore et al. 2006), our interviewees connected WLS with pleasant work, professional development and job security. Only one interviewee narrated continuous low WLS. This blue-collar worker explained that her work at Posti Group has always been physically heavy and insecure by nature. 


\section{Excerpt 2}

1 Well you can put, it's been so solid

2 solidly, one can say hard labor,

3 insecure, physically heavy and it's been

4 your regular type of work life like nothing,

5 like I understand real well that

6 someone might be (there) even in a job

7 that, that one might enjoy, even though I

8 haven't had any of that ever.

(I1, blue-collar worker, female, 57)
No kuule pistä, kuule se on ollu niin tasasta ja tasasen saa sanoo raskasta työtä, epävarmaa, fyysisesti raskasta ja, se on ollu kuule tavallisen se työelämä on ollu niin että ei mitään, mä ymmärrän kamala hyvin että joku vois olla (siel) jopa semmosessa työssä työssä että se vois viihtyä, vaikka mä en oo kokenu sitä koskaa.

On line 1 , the interviewee refers to the drawing task by telling the interviewer what to mark down ('Well you can put, it's been so solid'). In line with the results of previous qualitative studies (e.g., McNeese-Smith 1999), interviewee number one associated her work dissatisfaction with feelings of insecurity and physically demanding work.

Majority of the WLS narratives $(87.5 \%)$ included numerous positive and negative vicissitudes and the basic storyline was not directly observable from the lifelines. Analysis of the critical incidents, nevertheless, suggests that on average, these narratives represent a storyline of decreasing WLS; at the age of 20-29, interviewees mentioned mainly positive incidents that increased their WLS - at the age of 50-59, they mentioned mainly negative incidents that decreased their WLS.

While interviewees evaluated their WLS at the ages of 20-29, they named various positive (20) and few negative (3) incidents. In seven narratives, WLS increased when the interviewee got a job from Posti Group (or previous employer). After finding employment, interviewees' WLS increased because (a) their work was satisfying and/or (b) their career was progressing. Four interviewees portrayed their work at Posti Group as fun and easy; the workload was reasonable and co-workers were friends. Interviewee number 35 described that when she was in her 20s, good relations with co-workers increased her WLS.

\section{Excerpt 3}

1 Postal service was, in those days, I was

2 there in the Central unit, sorting mail, so

3 there it was really great, cause you had

4 lots of people of my age, and we had,

5 part of us, I met my in fact my

6 best friend there and we're still real

7 good friends, so like I found

8 in postal service, and there's others with

9 whom I've been in contact for years

10 on end. It was perhaps

11 in fact I'd say it was a real pleasant

12 time on the job, even though it was the

13 sorting in the postal service, but we had

14 a great bunch of people and had, we spent

15 free time together with part of the bunch

16 so it was real pleasant.

(I35, white-collar worker, female, 50)
Ja se Posti oli sillon mä olin siel

Postikeskuksessa, lajittelijana niin siel oli silleen oikeesti, mahtavaa kun siel oli semmosii mun ikäsii tosi paljon et meil oli, ja siel osa, mä oon saanu sieltä itse asias mun parhaan kaverinkin, jonka kaa ollaan edelleen tosi hyvii ystäviä niin, oon löytäny sielt Postista ja sielt on muitakin semmosia, joitten kaa on ollu vuosikausii sen jälkeen. yhteydessä. Se oli ehkä semmonen, itse asias mä sanosin että se oli, tosi mukavaa työelämäaikaa et vaik se oli sitä Postin lajitteluu, niin siel oli niin mahtava porukka ja meil oli, me vietettiin osan porukan kaa myös vapaa-aikaa sitten yhessä, niin se oli tosi kivaa. 
In line with the results of previous qualitative studies (Atefi et al. 2014; McNeese-Smith 1999), these interviewees connected WLS with a balanced workload and good social relationships. In addition, seven interviewees connected WLS with professional development. Permanent employment contracts, pay raise, change of unit and managerial duties increased these interviewees' WLS. Compared to positive incidents, interviewees mentioned only a few negative incidents. Nevertheless, three interviewees described that at the ages of 20-29, insecure, fixed-term employment contracts and heavy night shifts reduced their work satisfaction.

While evaluating their WLS at the ages of 30-39 interviewees mentioned both positive (10) and negative (8) incidents. All positive incidents were about professional development. The interviewees talked about new positions, new challenging assignments, and managerial duties. Two interviewees explained how permanent employment contract increased their work satisfaction. Interviewee number two, for example, described how signing a permanent employment contract that put a stop to working as a substitute increased his WLS.

\section{Excerpt 4}

1 There it starts a bit to, I think I got,

2 there I got my own delivery route that

3 I got to choose myself, and had no more

4 sick leave or holiday substitution

5 so it goes up a bit there...that

6 but the wages we had were quite modest

7 of course, so it does not go up

8 all the way to the top cause of that [laughs]

(I2, blue-collar worker, male, 65)

\author{
Tossa pikkuisen tulee, mää taisin siitä niin \\ siitä, mä sain oman jakelupiirin jonka sain \\ itse valita ja se, pysy pois nää sairasloman \\ sijaisuudet ja tämmöiset lomasijaisuudet niin \\ se pikkuisen nousee, siinä vaiheessa toi... \\ mutta meillähän oli, aika vaatimaton palkka \\ tietenkin mutta, se ei nouse ihan tonne \\ huippuun asti sen takia [nauraa].
}

On lines 1, 5 and 7-8, the interviewee refers to the lifeline he simultaneously draws ("There it starts a bit to - - so it goes up a bit there - - so it does not go up all the way"). Although getting a delivery route and permanent employment contract increased his WLS, low salary kept the satisfaction at a moderate level. Salary has been denominated as a source of satisfaction also in previous qualitative studies (e.g., Zembylas \& Papanastasiou 2006).

Although managerial duties were mainly associated with professional development and increasing WLS, one interviewee argued that managerial duties reduced his WLS. Instead of professional development, this interviewee portrayed such duties as an unnecessary source of stress.

At the age of 30-39, professional retrogression started to decrease interviewees' WLS. Four interviewees discussed dismissal from a previous position, new meaningless assignments and the loss of managerial duties. This result is in line with our quantitative analysis, according to which low job control (e.g., doing unimportant and insignificant work) is connected with decreasing WLS. Besides professional retrogression, weakening working conditions and health problems emerged in the WLS narratives. This is interesting considering that according to our quantitative analysis, perceived poor health and feelings of unequal treatment at work predicted decreasing trajectory of WLS. Continuous cooperation negotiations reduced WLS in one narrative and exhaustion and 
burnout in two narratives. Interviewee number 27 described how she experienced a burnout before turning 40 .

\section{Excerpt 5}

1 So. How low should I drop this now.

2 Let's put it that low. Here it was still OK.

3 I wonder was it already there at some point

4 the first so-called burnout. I'll put down

5 exhaustion. Worked too much. Thought

6 you could do however much with no

7 problem. But turned out you can't.

(I27, blue-collar worker, female, 60)
Nii. Kuinka alas mä nyt tätä tiputtaisin. Pannaan nyt noin alas. Täs oli OK vielä.

Jokohan tuolla oli jossain vaiheessa, ensimmäinen niin sanottu burnout. Pistetään uupumus. Tein liikaa töitä. Luulin että voi tehdä kuinka paljon vaa ettei siin oo mitään. Mut ei sitä sit voinukaan.

On lines 1-3, the interviewee refers to the lifeline she simultaneously draws ('How low should I drop this now'). Burnout is connected to poor health, which - according to our quantitative analysis - predicts decreasing trajectory of WLS.

While evaluating their WLS at ages 40-49, interviewees mentioned some positive (7) but even more negative (14) incidents. All positive incidents were again about professional development. Interviewees talked about new work positions and new challenging assignments. Negative incidents that decreased WLS were professional retrogression, stress and other health problems, and weakening working conditions. In eight narratives, professional retrogression or stress caused by managerial duties decreased WLS. Five interviewees talked about new assignments that were simple, meaningless or less challenging. One specific problem mentioned was the loss of banking services. Until 2000, Finnish postal services collaborated with Post Bank (later Leonia) and banking services were an important part of work at postal services. Interviewee number 38 , for example, described how the loss of banking services changed her job for the worse.

\section{Excerpt 6}

1 Yeah it was around 45 when the bank

2 services stopped, and that was an awful time

3 for real, it was. Cause that's when the work

4 profile changed into something so boring- -

5 like all you ever studied, and learned was

6 suddenly taken away, you see. It was

7 like you had never done any of that.

(I38, blue-collar worker, female 60)
Joo se oli joku 45 kun loppu sit pankkipalvelut, se oli kamalaa aikaa ihan oikeesti, se oli. Koska sit se työnkuva muuttu sit niin tylsäksi, - - et kaikki mitä sä olit opiskellu, ja opetellu, niin sitten yhtäkkiä sulta viedään kato kaikki pois. Et sä niinku, ihan ku ikinä ei ois mitään tehnytkään.

In two narratives, health problems reduced WLS. One interviewee described a burnout before the age of 50 and another one described bad back problems that started when she was 45. In three narratives, weakening working conditions reduced WLS. Interviewees talked about constant cooperation negotiations and feelings of insecurity and inequality that followed. Interviewee number 22 described how the first cooperation negotiations changed the atmosphere at the workplace for the worse. 
Excerpt 7

1 Yeah...the work atmosphere changed.

Joo... työilmapiiri muuttuu. Koska oikeestaan

2 Cause that's when the, hang on, 2005 I was,

3 I had the first big cooperation negotiations.

4 I'd have been just under fifty at that point.

5 I'll mark here that work atmosphere

6 changed. Atmosphere changed. sillon ne tommoset, ootas 2005 mä olin, mul sattu ensimmäiset isot yt:t kohdalle.

Mä oon ollu vajaan viidenkymmenen sillon.

Mä laitan et työilmapiiri muuttuu.

7 Let's mark that cooperation negotiations

Piiri muuttuu.

8 start.

Pannaan et yt:t, alkaa.

(I22 white-collar worker, female, 60)

On line 5, the interviewee refers to her drawing ('I'll mark here that work atmosphere changed'). She drew a downward lifeline.

While evaluating their work satisfaction at ages 50-59, interviewees mentioned few positive (4) and mainly negative (17) incidents. The positive incidents were new employment after layoff from Posti Group and early exit from Posti Group. The most discussed negative incident was, understandably, layoff from Posti Group. Other frequently mentioned negative incidents that reduced WLS were health problems and weakening working conditions. At the ages of 50-59, health problems varied from exhaustion and depression to back problems and cancer. Weakening working conditions were connected with constant cooperation negotiations and feelings of insecurity and loss of commonality that followed. Interviewee number 20 also talked about increasing managerial control and a loss of autonomy.

\section{Excerpt 8}

1 Here it just continues, so it started there

2 already I mean the general feeling and stuff

3 that meant it no longer was as pleasant

4 to be there, let's say that it turned into

5 like snooping. Our chief might like

6 check on whether someone went for a

7 smoke or the toilet, or if you exchanged a

8 few words in the morning with someone,

9 then the chief asks like: 'are you talking

10 business'.

(I20 blue-collar worker, female, 61)

Täst nyt sit tämä vaan, jatkaa, et se lähti tuolla jo siis se yleinen semmonen ilmapiiri ja muu että siellä ei ollu niin kiva enää olla kun siis, sanotaanko että se meni semmoseksi kyttäämiseksi. Meillä päällikkö saatto siis käyä kattomas onko joku menny tupakalle tai vessaan tai, jos sä vaihoit jonkun kanssa aamulla muutaman sanan niin päällikkö tulee sanomaan että 'puhutteko työasiaa'.

On lines 1-2, the interviewee refers to the downward lifeline on her drawing ('Here it just continues'). Likewise, our quantitative analysis demonstrated the connection between low job control and decreasing WLS.

\section{Conclusion}

In this article, we used quantitative and qualitative methods to study postal service workers' evaluations of WLS in the context of company downsizing. The results of quantitative and qualitative analysis mirrored each other. In both data, evaluations 
constituted trajectories of high and/or moderately high, low and decreasing WLS. While some workers reported rather stable satisfaction or dissatisfaction with work, others reported decrease in WLS.

Our quantitative analysis demonstrated that almost one third of respondents reported a decreasing WLS. The analysis also demonstrated that sharply decreasing WLS was associated with (a) poor health and work ability, and (b) experiences of unequal treatment, low job support and low job control. Our qualitative analysis demonstrated that in lay conceptions, decrease in WLS was commonly associated with (a) health problems (i.e., poor health and work ability in quantitative analysis), and (b) professional retrogression and weakening working conditions (i.e., unequal treatment, lowered job control and job support in quantitative analysis). In lay conceptions, health problems included psychological problems such as stress, exhaustion and depression, and physiological problems such as musculoskeletal diseases and cancer. Professional retrogression was associated with less meaningful or insignificant tasks and loss of managerial duties. Weakening working conditions were connected with constant cooperation negotiations and layoffs that, according to our interviewees, lead to feelings of unequal treatment and insecurity. Furthermore, constant cooperation negotiations were associated with a loss of communality and job support (also Luomanen et al. 2018).

The comparison with the existing literature suggests that our findings are plausible. Previous studies have also connected work satisfaction and wellbeing at work with job control, job support and feelings of organizational justice (e.g., Lindfors et al. 2007; Meyers et al. 2019; Pagán 2013; Waddimba et al. 2016). However, we found no significant differences in WLS pathways among white-collar and blue-collar workers or among men and women. This finding contradicts some previous studies (e.g., Lindfors et al. 2007; Navarro \& Salverda 2019; Qian \& Fan 2019).

Our quantitative and qualitative analysis both demonstrated that WLS started to decrease when our respondents and interviewees were in their 30s. At that age, health problems, professional retrogression and weakening working conditions emerged in the WLS narratives. Since our respondents and interviewees were born in the 1950s and 1960s, they were in their 30s in the 1980s and 1990s. At that time, Finnish postal services were facing massive changes (Pietiäinen 1998). Finnish government agencies transformed into commercial enterprises in 1980s and the 1990s, and postal services became an enterprise at the beginning of 1990s. These changes had an influence on numerous workers' job descriptions. Furthermore, employee downsizings started soon after. The qualitative part of this study highlights that besides age and health, numerous contextual factors contribute to WLS. Finnish postal service workers argued that constant co-operation negotiations and employee downsizings reduced their WLS. These results suggest that Posti Group has failed to organize employee downsizings in a way that would have mitigated negative repercussions, such as workers' decreased WLS and happiness. From political perspective, this result is alarming. Population in the Nordic countries is aging. The number of older people is increasing and the number of working age population is expected to shrink (Grunfelder et al. 2018b). Because of these demographic changes, it is crucial to extend working careers. However, previous studies demonstrate that when people are not satisfied with their working life, they do not want to delay retirement age.

Like most empirical studies, our study has strengths and limitations. It is clear that the use of both quantitative and qualitative methods is a strength of our study. In the quantitative part of the study, use of different lifetime points allowed us to investigate 
the pathways of WLS in a way previous studies have not been able to do. However, the fact that respondents evaluated their general life satisfaction just before they evaluated their WLS engenders the possibility of a recall bias. Nonetheless, the authors believe that the use of mixture modeling has controlled it to an extent by mixing the analogous responses into the separate classes. In the qualitative interview study, the use of biographical lifelines to map changes in WLS produced rich data where interviewees evaluated the incidents that increased or decreased their work satisfaction in detail. This, according to Flanagan (1954), is crucial to the credibility of the findings (also Butterfield et al. 2005). Regarding the data analysis, we were interested in interviewees' lay conceptions and how the respondents themselves identified the critical incidents that affected their WLS. The reader is able to evaluate intelligibility of the categorization of these incidents from the extracts provided in the results chapter.

\section{Acknowledgements}

This research was supported by the Kone Foundation [5011cc] and The Finnish Work Environment Fund [115440]. KC P was partly funded by a personal working grant from The Ella and Georg Ehrnrooth Foundation grant, 2019. The authors are grateful to Elisa Virkola (D.Soc.Sc) for her contribution in data generation.

\section{References}

Allan, B. A., Dexter, C., Kinsey, R. \& Parker, S. (2018). Meaningful work and mental health: job satisfacation as a moderator, Journal of Mental Health 27(1): 38-44. doi: https://doi. org/10.1080/09638237.2016.1244718.

Armstrong-Stassen, M. \& Cattaneo, J. (2010). The effect of downsizing on organizational practices targeting older workers, Journal of Management Development 29(4): 344-363. doi: https://doi.org/10.1108/02621711011039150.

Atefi, N., Abdullah, K. L., Wong, L. P. \& Mazlom, R. (2014). Factors influencing registered nurses perception of their overall job satisfaction: a qualitative study, International Nursing Review 61: 352-360. doi: https://doi.org/10.1111/inr.12112.

Badran, M. \& Kafafy, J. (2008). The effect of job redesign on job satisfaction, resilience, commitment and flexibility: The case of an Egyptian public sector bank, International Journal of Business Research 8(3): 1-18.

Berglund, T., Seldén, D. \& Halleröd, B. (2017). Factors Affecting Prolonged Working Life for the Older Workforce: the Swedish Case, Nordic Journal of Working Life Studies 7(1): 19-36. doi: https://doi.org/10.18291/njwls.v7i1.81396.

Bojanowska, A. \& Zalewska, A. (2016). Lay Understanding of Happiness and the Experience of Well-being: Are some Conceptions of Happiness More Beneficial than Others? Journal of Happiness Studies 17(2): 793-815. doi: https://doi.org/10.1007/s10902-0159620-1.

Bussing, A., Bissels, T. \& Fuchs, V. (1999). A Dynamic Model of Work Satisfaction: Qualitative Approaches, Human Relations 52 (8): 999-1028. doi: https://doi.org/10.1023/ A:1016979523846.

Butterfield, L. D., Borgen, W. A., Amundson, N. E. \& Maglio, A-S. T. (2005). Fifty years of the critical incident technique: 1954-2004 and beyond, Qualitative Research 5(4): 475-497. doi: https://doi.org/10.1177/1468794105056924. 
Chao, M. C., Jou, R. C., Liao, C. C. \& Kuo, C. W. (2015). Workplace stress, job satisfaction, job performance, and turnover intention of health care workers in rural Taiwan, Asia-Pacific Journal of Public Health 27(2): NP1827-1836. doi: https://doi.org/ $10.1177 / 1010539513506604$.

Datta, D. K., Guthrie, J. P., Basuil, D. \& Pandey, A. (2010). Causes and Effects of Employee Downsizing: A Review and Synthesis, Journal of Management 36(1): 281-348. doi: https://doi.org/10.1177/0149206309346735.

de Wesley, A. B. \& Clemson, L. (1992). Job satisfaction issues: The focus group approach, Australian Occupational Therapy Journal 39: 7-15. doi: https://doi.org/10.1111/j. 1440-1630.1992.tb01762.x.

Dieke, A., Bender, C., Campbell, J. Cohen, R., et al. (2013). Main developments in the Postal Sector (2010-2013), Wiik Consult, Final Report.

Dolbier, C. L., Webster, J. A., McCalister, K. T., Mallon, M. W., Steinhardt, M. A. (2005). Reliability and validity of a single-item measure of job satisfaction, American journal of health promotion: AJHP 19(3): 194-198. doi: https://doi.org/10.4278/0890-117119.3.194.

Eläketurvakeskus (2013). Suomen eläkejärjestelmän sopeutuminen eliniän pitenemiseen. Eläkekysymysten asiantuntijatyöryhmän raportti, Helsinki: Eläketurvakeskus.

European Commission (2010). Progress and key challenges in the delivery of adequate and sustainable pensions in Europe, Brussels: European Commission.

Flanagan, J. C. (1954). The Critical Incident Technique, Psychological Bulletin 51: 327-358. doi: http://dx.doi.org/10.1037/h0061470.

Furunes, T. \& Mykletun, R. (2010). Age discrimination in the workplace: Validation of the Nordic Age Discrimination Scale (NADS), Scandinavian Journal of Psychology 51(1): 23-30. doi: https://doi.org/10.1111/j.1467-9450.2009.00738.x.

Grunfelder, J., Rispling, L. \& Norlén, G. (eds.) (2018a). State of the Nordic Region 2018. Theme 1: Demography. Copenhagen: Nordic Council of Ministers.

Grunfelder, J., Rispling, L. \& Norlén, G. (eds.) (2018b). State of the Nordic Region 2018. Theme 2: Labour Force. Copenhagen: Nordic Council of Ministers.

Harkonmäki, K., Martikainen, P., Lahelma, E., et al. (2009). Intentions to retire, life dissatisfaction and the seubsequent risk of disability retirement, Scandinavian Journal of Public Health 37(3): 252-259. doi: https://doi.org/10.1177/1403494808100273.

Hess, M. (2017). Rising Preferred Retirement Age in Europe: Are Europe's Future Pensioners Adapting to Pension System Reforms? Journal of Aging \& Social Policy 29(3): 245-261. doi: https://doi.org/10.1080/08959420.2016.1255082.

Itella. Vuosikertomus ja Yritysvastuuraportti (2011). (Itella annual report and corporate responsibility report 2011). http://vuosikertomus2011.posti.com/UserFiles/itella/File/pdf/ Itella_2011 Suomi.pdf. (Accessed 3 December 2018).

Itella. Vuosikertomus ja Yritysvastuuraportti (2012). (Itella annual report and corporate responsibility report 2012). http://vuosikertomus2012.itella.fi/UserFiles/itella/ File/2012/220838 Itella vsk 2012 SUOMI.pdf. (Accessed 3 December 2018).

Itella. (2013). Vuosikertomus. (Itella annual report 2013). http://annualreport2013.itella. com/filebank/1332-Itella Vuosikertomus 2013.pdf. (Accessed 3 December 2018).

Jääskeläinen, A., Kausto, J., Seitsamo, J. et al. (2016). Workability index and perceived workability as predictors of disability pension: a prospective study among Finnish municipal employees, Scandinavian Journal of Work, Environment \& Health 42(6): 490-499. doi: https://doi.org/10.5271/sjweh.3598.

Kadefors, R., Schaller, J., Thång, P.-O. \& Pestat, E. (2016). Attitudes among Male and Female University Professors, and other Categories of University Employees, to Working up to and Beyond Normal Retirement Age, Nordic Journal of Working Life Studies 6(1): 133-146. doi: https://doi.org/10.19154/njwls.v6i1.4913. 
Kuoppala, J., Lamminpää, A., Väänänen-Tomppo, I. \& Hinkka, K. (2011). Employee well-being and sick leave, occupational accident, and disability pension: a cohort study of civil servants, Journal of Occupational and Environmental Medicine 53(6): 633-640. doi: https://doi.org/10.1097/JOM.0b013e31821aa48c.

Lindfors, P. M., Meretoja, O. A., Töyry, S. M., Luukkonen, R. A., Elovainio, M. J. \& Leino, T. J. (2007). Job satisfaction, work ability and life satisfaction among Finnish anesthesiologists, Acta Anaesthesiologica Scandinavica 51(7): 815-822. doi: https://doi.org/10.1111/ j.1399-6576.2007.01343.x.

Locke, E. A. (1976). The nature and causes of job satisfaction, In M. D. Dunnette (ed.), Handbook of industrial and organizational psychology (pp. 1297-1351). New York: Wiley.

Lunau, T., Bambra, C., Eikemo, T. A., van der Wel, K. A. \& Dragano, N. (2014). A balancing act? Work-life balance, health and well-being in European welfare states, The European Journal of Public Health 24(3): 422-427. doi: https://doi.org/10.1093/eurpub/cku010.

Luomanen, J., Lumme-Sandt, K., Virkola, E. \& Nikander, P. (2018). Kadonnut yhteisö? Postilaisuus ikääntyvien Postin työntekijöiden haastattelupuheessa, Työelämän tutkimus Arbetslivsforskning 16 (3): 154-168.

Macky, K. A. (2004). Organisational Downsizing and Redundancies: The New Zealand Workers Experience, New Zealand Journal of Employment Relations 29(1): 63-87.

Mäkikangas, A. \& Kinnunen, U. (2003). Psychosocial work stressors and well-being: selfesteem and optimism as moderators in one-year longitudinal sample, Personality and Individual Differences 35: 537-557. doi: https://doi.org/10.1016/S0191-8869(02)00217-9.

McMullin, J.A. \& Marshall, V.W. (2001). Ageism, age relations, and garment industry work in Montreal, Gerontologist 41(1): 111-122. doi: https://doi.org/10.1093/geront/41.1.111.

McNeese-Smith, D. K. (1999). A content analysis of staff nurse descriptions of job satisfaction and dissatisfaction, Journal of Advanced Nursing 29(6): 1332-1341. doi: https://doi. org/10.1046/j.1365-2648.1999.01018.x.

Meier, L. L., Tschudi, P., Meier, C. A., Dvorak, C. \& Zeller, A. (2015). When general practitioners don't feel appreciated by their patients: prospective effects on well-being and work-family conflict in a Swiss longitudinal study, Family Practice 32(2): 181-186. doi: https://doi.org/10.1093/fampra/cmu079.

Meyers, M. C., Adams, B. G., Sekaja, L., Buzea, C., Cazan, A-M., Gotea, M., et al. (2019). Perceived organizational support for the use of employees' strengths and employee wellbeing: a cross-country comparison, Journal of Happiness Studies 20(6): 1825-1841. doi: https://doi.org/10.1007/s10902-018-0026-8.

Moore, K., Cruickshank, M. \& Haas, M. (2006). Job satisfaction in occupational therapy: a qualitative investigation in urban Australia, Australian Occupational Therapy Journal 53: 18-26. doi: https://doi.org/10.1111/j.1440-1630.2006.00539.x.

Muthén, B. (2003). Statistical and substantive checking in growth mixture modeling: comment on Bauer and Curran, Psychological Methods 8(3): 369-377. doi: https://doi. org/10.1037/1082-989X.8.3.369.

Navarro, M. \& Salverda, W. (2019). Earner position and job and life satisfaction: Do contributions to the household income have the same effect by gender and occupations. Journal of Happiness Studies 20(7): 2227-2250. doi: https://doi.org/10.1007/s10902018-0045-5.

Neale, B. (2019). What is Qualitative Longitudinal Research? London: Bloomsbury.

Nikander, P. (2008). Working with Transcripts and Translated Data, Qualitative Research in Psychology 5(3): 225-231. doi: https://doi.org/10.1080/14780880802314346.

Nylund, K. L., Asparouhov, T. \& Muthén, B. O. (2007). Deciding on the Number of Classes in Latent Class Analysis and Growth Mixture Modeling: A Monte Carlo Simulation Study, Structural Equation Modeling: A multidisciplinary Journal 14(4): 535-569. doi: https://doi.org/10.1080/10705510701575396. 
OECD (2017). OECD recommends Finland to do more to help older people stay in work. http://www.oecd.org/finland/oecdrecommendsfinlandtodomoretohelpolderpeoplestayinwork.htm. (Accessed 4 October 2017).

Pagán, R. (2013). Job Satisfaction and Domains of Job Satisfaction for Older Workers with Disabilities in Europe, Journal of Happiness Studies 14(3): 861-891. doi: https://doi. org/10.1007/s10902-012-9359-x.

Pietiäinen, J-P. (1998). Postia kaikille. Suomen Postin tarina 1638-1998. Helsinki: Edita.

Posti (2014). Vuosikertomus 2014. (Posti Group annual report 2014). http://annualreport2014. posti.com/filebank/1447-Posti Vuosikertomus 2014.pdf. (Accessed 3 December 2018).

Posti (2015). Vuosikertomus 2015. (Posti Group annual report 2015). http://annualreport2015. posti.com/filebank/1230-POSTI Vuosikertomus 2015.pdf. (Accessed 3 December 2018).

Posti (2016). Vuosikertomus 2016. (Posti Group annual report 2016). http://annualreport2016.posti.com/filebank/800-Posti VSK16 FI.pdf. (Accessed 3 December 2018).

Qian, Y. \& Fan, W. (2019). Men and women at work: Occupational gender composition and affective well-being in the United States. Journal of Happiness Studies 20(7): 2077-2099. doi: https://doi.org/10.1007/s10902-018-0039-3.

Ramoo, V., Abdullah, K. L., Piaw, C. Y. (2013). The relationship between job satisfaction and intention to leave current employment among registered nurses in a teaching hospital. Journal of Clinical Nursing 22: 3341-3152. doi: https://doi.oreg/10.1111/jocn.12260.

Sagie, A. (1998). Employee Absenteeism, Organizational Commitment, and Job Satisfaction: Another Look, Journal of Vocational Behavior 52: 156-171. doi: https://doi.org/10.1006/ jvbe.1997.1581.

Siegrist, J., Wahrendorf, M., Von dem Knesebecko, O., Jürges, H. \& Börsch-Supan, A. (2007). Quality of work, well-being, and intended early retirement of older employees: Baseline results from the SHARE study, European Journal of Public Health 17: 62-68. doi: https:// doi.org/10.1093/eurpub/ck1084.

Shimazu, A. \& Schaufeli, W. B. (2009). Is workaholism good or bad for employee well-being? The distinctiveness of workaholism and work engagement among Japanese employees, Industrial Health 47: 495-502. https://doi.org/10.2486/indhealth.47.495.

Solem, P-E. (2016). Ageism and age discrimination in working life, Nordic Psychology 68(3): 160 -175. doi: https://doi.org/10.1080/19012276.2015.1095650.

Spector, P. E. (1997). Job satisfaction: Application, assessment, causes and consequences. Thousand Oaks: Sage.

Stynen, D., Jansen, N. W., Slangen, J. J. \& Kant, I. (2016). Impact of development and accommodation practices on older workers' job characteristics, prolonged fatigue, work engagement, and retirement intentions over time, Journal of Occupational and Environmental Medicine 58(11): 1055-1065. doi: https://doi.org/10.1097/JOM.0000000000000853.

Tay, L. \& Harter, J. K. (2013). Economic and labor market forces matter for worker well-being, Applied Psychology: Health \& Well-Being 5(2): 193-308. doi: https://doi. org/10.1111/aphw.12004.

van den Berg, T. I. J., Elders, L. A. M. \& Burdorf, A. (2010). Influence of Health and Work on Early Retirement, Journal of Occupational and Environmental Medicine 52(6): 576-583. doi: https://doi.org/10.1097/JOM.0b013e3181de8133.

Virtanen, M., Kivimäki, M., Elovainio, M., Vahtera, J. \& Ferrie, J. E. (2003). From insecure to secure employment: changes in work, health, health related behaviours, and sickness absence, Occupational and Environmental Medicine 60(12): 948-953. doi: https://doi. org/10.1136/oem.60.12.948.

von Bonsdorff, M. B., Seitsamo, J., von Bonsdorff, M. E., et al. (2012). Job strain among blue-collar and white-collar employees as a determinant of total mortality: a 28 -year population based follow-up, BMJ Open 2(2). doi: http://dx.doi.org/10.1136/bmjopen-2012-000860. 
Waddimba, A. C., Scribani, M., Krupa, N., May, J. J. \& Jenkins, P. (2016). Frequency of satisfaction and dissatisfaction with practice among rural-based, group employed physicians and non-physician practitioners, BMC Health Services Research 16(1): 613. doi: https:// doi.org/10.1186/s12913-016-1777-8.

Wise, D. (2010). Facilitating longer working lives: international evidence on why and how, Demography 47 (supplement): S131-S149. doi: https://doi.org/10.1353/dem.2010.0000.

Zembylas, M. \& Papanastasiou, E. (2006). Sources of teacher job satisfaction and dissatisfaction in Cyprus, Compare: A Journal of Comparative and International Education 36(2): 229-247. doi: https://doi.org/10.1080/03057920600741289. 


\section{Appendix}

Table A I Qualitative data used in the project

\begin{tabular}{lc}
\hline Qualitative data & Amount \\
\hline Face-to-face interviews & 40 ( $^{\text {st }}$ round $)+32$ \\
& $\left(2^{\text {nd }}\right.$ round $)$ \\
Telephone interviews & 107 \\
Video diaries & 216 \\
Journals & 17 \\
e-mails & 18 \\
\hline
\end{tabular}

Figure A I Coordinate plane given to the interviewees

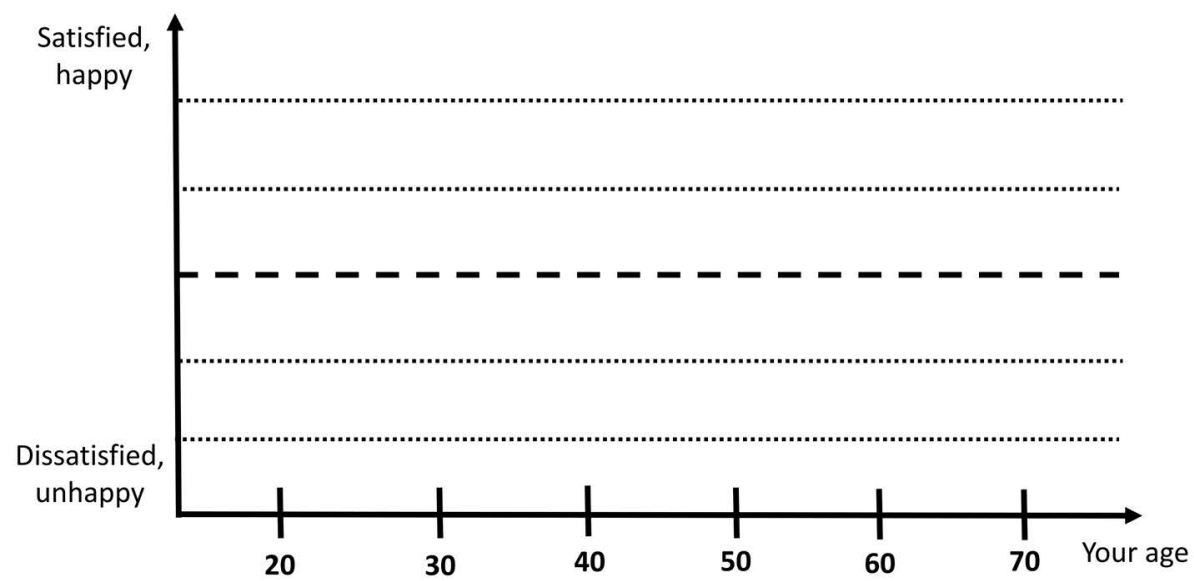

Describe your satisfaction and happiness at work by drawing a graph in the above table 